\title{
SELF-AWARENESS AND SELF-PRESENTATION PUPIL IN CONNECTION WITH ITS DECISION MAKING CAREER
}

\author{
Jiř́ KROPÁC̆ - Anna ZUBATÁ - Jitka PLISCHKE
}

\begin{abstract}
General educational programs, which are implemented today in the educational practice of schools, require students' preparation to find their place in the world of work. The article focuses on selected context of the students' preparation for career decision, especially on connections between the self-knowledge and self-presentation of students, namely which are based on the findings of student's opinions on the preparation in secondary schools using a questionnaire.

Key words: self-awareness, self-presentation, general educational program (World of work).

\section{SEBEPOZNÁNÍ A SEBEPREZENTACE ŽÁKA V SOUVISLOSTI S JEHO KARIÉROVÝM ROZHODOVÁNÍM}

Resumé: Rámcové vzdělávaci programy, uváděné v současnosti do vzdělávaci praxe škol, požaduji prípravu žáků na hledáni svého mista ve světě práce. Stat'je zaměrena na vybrané souvislosti prípravy žáki̊ na kariérové rozhodování, predevším na souvislosti sebepoznáni a sebeprezentace žáka, a to i na základě zjištěni názori̊ žáků na př́pravu na středních školách pomocí dotazníku.

Kličcová slova: sebepojetí, sebeprezentace, rámcový vzdělávací program (Svět práce)

\section{1 Úvod}

Profesní orientace, popř. kariérové rozhodování, jak zní stále častěji používaný termín, představuje pro žáka a jeho rodinu významnou a obtížnou situaci; volba profese je především záležitostí žáka a rodiny (1). Začíná nejpozději v nižším sekundárním vzdělávání, pro žáky víceletých gymnázií i dř́ive. Zde probíhá první volba profesní orientace, první kariérové rozhodování. Následně ovšem, na střední škole nebo také později, může probíhat druhé kariérové rozhodování (změna nebo výběr z variant výkonu profese), jen málokomu se poštěstí, aby tato rozhodování byla poslední. Každé z těchto rozhodnutí musí respektovat jak danosti rozhodujícího se, tak vyžaduje znalosti pracovního trhu. Potom může následovat „,dobré rozhodnutí". Na straně jedné je tedy třeba, aby rozhodující se, v našem př́ípadě žák, znal nejen podmínky pracovního trhu, možnosti, údaje o profesích, o způsobu jejich výkonu a o nárocích a př́pravě na ně. Na straně druhé si musí uvědomovat své danosti, zájmy, schopnosti, temperament, musí znát sám sebe. Psychologie i pedagogika zde použíá pojmy jako sebepoznání, sebepojetí, sebehodnocení, viz dále.

Podmínkou úspěšné realizace dobrého rozhodnutí je dnes stále více schopnost dobré sebeprezentace. Formu může mít písemnou nebo osobní (dnes i pomocí ICT). Jako opodstatněný považujeme názor, že není možná úspěšná sebeprezentace bez adekvátního sebepoznání (a bez znalostí o profesi). V dalším textu se zaměříme na prostor, pozornost či naléhavost, jaký dávají v současnosti zaváděné Rámcové vzdělávací programy (dále RVP) žákovu sebepoznání a sebeprezentaci prováděné z hlediska světa práce. Nejprve si ale krátce povšimneme soudobých trendů světa práce. Po analýze souvisejících pojmů budeme prezentovat výsledky dotazníkového šetření a navrhneme rámcová opatření v činnosti učitele technických předmětů, která by přinášela možnosti hlubšího sebepoznání žáka a zvýšila by možnosti adekvátní sebeprezentace.

2 Soudobé trendy světa práce a všeobecné předpoklady pro uplatnění na trhu práce

$\mathrm{V}$ profesních organizacích probíhají dnes restrukturalizace směřující ke snížení počtu hierarchických úrovní řízení a počtu zaměstnanců, $\mathrm{k}$ dosažení maximální flexibility (2), (3). Z hlediska uplatnění zaměstnanců to znamená spojení hlubokých znalostí se širší specializací, flexibilitou, větší odpovědností a samostatností a naopak menší jistotu zaměstnání.

$\mathrm{V}$ anketě mezi velkými zaměstnavateli $\mathrm{v}$ Moravskoslezském kraji byly za nejvýznamnější označeny tyto „široké“ vlastnosti či kompetence pracovníka/uchazeče: - komunikativnost, kooperativnost, - podnikavost, - flexibilita, uspokojování zákaznických potřeb, - výkonnost, samostatnost, - řešení problémů, - plánování a organizování práce, - celoživotní učení, - aktivita, 
- zvládání zátěže, - objevování informací a orientace $\mathrm{v}$ nich, - komunikace $\mathrm{v}$ cizích jazycích, podrobněji viz (4). Je ovšem známo, že se liší požadavky velkých zaměstnavatelů hodnotících více „obecnější vzdělanost“ uchazečů o práci a tedy uvedené komplexní kompetence (viz výše, pro konkrétní činnost si zaměstnance zaškolí) a požadavky malých firem na zvládnutí konkrétní činnosti k jejímu bezprostřednímu výkonu.

Uvedená charakteristika světa práce i pres svoji stručnost ukazuje mnohost, odlišnost prováděných profesí, význam schopnosti jednat, komunikovat $\mathrm{s}$ jinými lidmi a nezbytnosti prrizpůsobení se podmínkám, přičemž jedinec musí vědět, co ještě může bez komplikací zvládnout. Zde tedy sebepoznání a sebeprezentace opět vystupuje jako významný faktor. Mohou mít tuto pozici i v učební dokumentaci škol? Tu dnes předurčují RVP.

\section{Rámcové vzdělávací programy a př́íprava na kariérové rozhodování}

K dosažení „způsobilosti“ dobrého kariérového rozhodování u žáka nižšího sekundárního vzdělávání pomáhá mj. práce výchovného poradce a výuka tematického okruhu Svět práce. V Rámcových vzdělávacích programech pro základní vzdělávání (dále RVP ZV) sestává vzdělávací oblast Člověk a svět práce, určená pro 2 . stupeň, z osmi tematických okruhů. Svět práce je z nich ,jediný povinný“; vhodný je do vyšších ročníků, viz (5). V následujícím textu kapitoly provedeme označení textu významného pro tuto stat' kurzívou. $\quad \mathrm{Na}$ základě př́slušné výuky je očekávána žákova orientace $\mathrm{v}$ pracovních činnostech vybraných profesí, posouzeni vlastnich možností při rozhodování o volbě vhodného povoláni a profesni prípravy, využití profesních informací a poradenské služby pro výběr vhodného vzdělávání, žák má také prokázat $v$ modelových situacich schopnost prezentace své osoby při vstupu na trh práce (5, s. 86). Obsah učiva tematického okruhu je zpracován $\mathrm{v}$ učebnici (6). Zde tedy je jednoznačné (viz text kurzívou), že jak sebepoznání, tak sebeprezentace je žádoucím vzdělávacím výsledkem.

V Rámcových vzdělávacích programech pro gymnázia je opět zastoupena vzdělávací oblast Člověk a svět práce, tematický okruh obdobný okruhu Svět práce v RVP ZV už ne, jeho záměry přebírají zejména tematické okruhy Trh práce a profesní volba a také Pracovněprávní vztahy. Další tematické okruhy mají charakter ekonomický (7). Z cílů této tematické oblasti se problematice stati výrazně dotýkají cíle uvozené vést žáka $\mathrm{k}$ „,uplatnění profesnich předpokladi̊ zodpovědným výběrem povoláni" a rovněž „dovednosti vhodně se prezentovat na veřejnosti, prezentovat výsledky své práce a svou práci adekvátně hodnotit". Tyto cíle mohou být naplněny okruhem vzdělávacího obsahu Trh práce a profesni volba. Je zřejmé, že příslušná vzdělávací oblast je „netechnicky“ zaměřena, poskytuje však dostatek prostoru pro adekvátní rozvíjení sebepoznání a způsobilost sebeprezentace žáka. Jde ale o to, že sebepoznání vzhledem $\mathrm{k}$ technickým profesím a $\mathrm{k}$ profesím využívajícím techniku nemůže být podložené.

V Rámcových vzdělávacích programech pro odborné vzdělávání (dále RVP OV) název Člověk a svět práce označuje prưřrezové téma (ne vzdělávací oblast) spočívající $\mathrm{v}$ přípravě na kariérové rozhodování. Obsahové celky podporující kariérové rozhodování jsou tedy zapracovány do vyučovacích předmětů. Jde o doplnění odborného vzdělávání o souvislosti uplatnění ve světě práce, o druhou volbu profesní orientace, o pomoc ,při rozhodování o další profesní a vzdělávací orientaci, při vstupu na trh práce a při uplatňování pracovních práv“", zde konkrétně dle $(8$, s. 61$)$.

Prưřezové téma přispívá $\mathrm{k}$ naplňování cílů vzdělávání mimo jiné v rozvoji těchto vybraných obecných kompetencí: - identifikace a formulováni vlastnich priorit; - odpovědné rozhodování na základě vyhodnoceni ziskaných informaci; - verbálni komunikace při důležitých jednánich; - pisemné vyjadřováni při úrední korespondenci. $\mathrm{V}$ obsahu prưřezového tématu lze, dle (8, s. 61-62), najít požadavky na žákovo zvládnutí písemné $i$ verbálni sebeprezentace při vstupu na trh práce, jednání s možným zaměstnavatelem, $u$ príímacího pohovoru; to podloženě o znalosti o profesi. Asi není přkvapením soulad prưřezového tématu s profesním zaměřením žáka. Zacílení pozornosti na sebeprezentaci i s aspektem vědomí vlastních možností svědčí o pozorném prístupu zpracovatelů RVP OV.

Ukázali jsme, že zacílení na sebepoznání a sebeprezentaci žáka je vRVP zřejmé. Nyní přejděme $\mathrm{k}$ analýze těchto a souvisejících pojmů.

\section{Sebepoznání, sebepojetí, sebehodnocení a rozhodování jako součást volby profese}

Dosud jsme $v$ tomto textu zjednodušeně použili jen „vybraný pojem“ sebepoznání. Je jednoduché nahlédnout do rejstrríků hodnotné 
pedagogické nebo psychologické literatury, např. (9, s. 644), a podívat se, kolik termínů začíná sebe- a souvisí se sebepoznáním.

Dále analyzované pojmy představují obecně významné cíle, významné jsou i ve vztahu ke kariérovému rozhodování. Jsou dosahovány především dobře voleným procesem výuky. Doplníme obecné vymezení těchto pojmů o vybrané souvislosti s volbou profesí a se sebeprezentací.

Sebepoznání je podle $(9$, s. 171, 331), (10, s. 9) přijímání informací o sobě včetně jejich vědomého začleňování do dřive přijatých informací, tedy do stávajícího sebepojetí (viz dále). Žákovo sebepoznání je naplňováno jako poznávání jeho potřeb, motivů, zájmů, emocí a myšlení; probíhá v konkrétních situacích. Důležité pro nás je, aby byly blízké budoucí profesi a umožnily vytvoření shrnujícího názoru žáka na jeho pozici vzhledem $\mathrm{k}$ dané profesi nebo okruhu profesí. Jde především o vědomí svých psychických vlastností, možností i omezení (rozumových, emočních, fyzických, způsobů myšlení aj.), porozumění svému rozvoji; to vše zde směřuje $\mathrm{k}$ porovnání $\mathrm{s}$ hospodářskými, profesními, popř. společenskými trendy. Žák si uvědomuje, zde s ohledem na volenou profesi, odpovědi na otázky - co jsem, co mohu zvládnout a které profese tomu odpovídají, co se dnes chce, popř. které profese jsou žádány, co chci já, $\mathrm{k}$ čemu se hodím, co mohu na sobě $\mathrm{z}$ tohoto hlediska změnit a chci to změnit, jaké mám návyky, jak se ovládám, trpím stresem, zvládám zátěž, jednám rád $\mathrm{s}$ lidmi, jsem extrovert nebo introvert, jaké jsou mé vztahy k lidem atp.

Shrňme - přiměřené sebepoznání je tedy podmínkou pro samostatné a přiměřené kariérové rozhodování žáka, pro uvědomění si svých daností a vytvoření si názoru na sebe (viz dále sebepojetí). Spolu se znalostmi o profesi to dává předpoklad $\mathrm{k}$ sebeprezentaci žáka, tedy k vnějšímu projevu jeho názorů „na sebe“ ve vztahu k profesi. V technických předmětech jsou dobré podmínky, aby žák prožil vlastní rozhodování, aby poznal sebe ve vztahu $\mathrm{k}$ technice porovnáním svých výsledků s ostatními žáky. Může také prožívat situace svou strukturou relativně blízké situacím profesním. Lze vytvořit i časový prostor pro shrnující zamyšlení, pro periodickou syntézu podněcovanou také dialogem učitele a žáka (11).

Sebepojetí je „přijatý výsledek“ sebepoznání žáka, závislý na informacích poskytovaných okolím (12, s. 246). Sebepojetí lze chápat jako výčet vlastností tělesných i duševních, výčet oblastí, v nichž má žák rozvinuté dovednosti a schopnosti (dosahuje v nich dobrých výsledků) i vědomí ke komu patř́ atp. Sebepojetí je vytvářeno na základě podnětů sociálních, osobnostních a situačních, z hlediska stati jsou významné situace spojené stechnikou a informačními technologiemi a to $\mathrm{v}$ situacích podobných profesi. Pro kariérové rozhodování je třeba rozlišovat: - jak se vidí žák - jak je tento jeho názor ovlivněn druhými lidmi (záměrnými nebo nezáměrnými sděleními, postoji) - jak by se vidět chtěl $(9$, s. 171-172). Pro adekvátní sebeprezentaci je třeba, aby sebepojetí přešlo do emočně-hodnotících souvislostí, sebehodnocení a seberozvoje. Učitel technických předmětů zde musí být pozorný, trpělivý a uznalý, povzbuzovat jej, nepřebírat však rozhodování (11).

Sebehodnocení, tedy postoj žáka k sobě samému, předurčuje i schopnost jeho výkonu. Neadekvátně nízké, negativní žákovo sebehodnocení je charakteristické názorem, že neúspěchy jsou dány jeho nedostatečnými předpoklady a nelze je změnit. Nejen pro kariérové rozhodování, ale pro celkový seberozvoj žáka je výhodné spís ",mírně vyšší“ sebehodnocení (12, s. 152). Také proto potřebuje být kladně hodnocen, což může být při přehnaně vysokém sebehodnocení kontraproduktivní.

Shrňme - v technických předmětech žák může své sebepoznání postupně upřesňovat, ovlivňovat, rozvíjet a přiměřeně využívat, tím může získávat přiměřené, stabilní, sebejisté sebepojetí a vytvořit si sebehodnocení, jež je výrazem zralosti žáka, předpokladem dobrého rozhodnutí i v náročné situaci jako je kariérové rozhodování. Tak jsou vytvářeny předpoklady $\mathrm{k}$ adekvátní věrohodné sebeprezentaci.

Nepovažujeme za potřebné se v této stati blíže zabývat pojmem sebeprezentace či prezentace své osoby, jeho chápání v souladu s RVP považujeme za adekvátní. S problémovým okruhem stati však souvisí pojem rozhodování.

Rozhodování dle (13, s.515) představuje volbu z možností, volbu té, o níž přepokládáme, že přinese žádoucí výsledky. Zpravidla je tedy při rozhodování více alternativ, je nezbytné vzít do úvahy více faktorů, informace jsou často neúplné. Rozhodování se týká volby cílů i prostředků. Ovlivněno je rozhodující se osobou (předsudky, emocemi, znalostmi i neznalostmi) a situací (vnějšími tlaky okolí, náladami, předpisy). Může být označováno jako živelné, konvenční, stereotypní, rutinní, plánovité aj. Př́i rozhodování podle D. Fontany (12, s. 117-118) používáme tř́iění i řadu dalších strategií. Obvyklý je, mj. dle 
(14, s. 428), postup rozhodování, který pro kariérové rozhodování zjednodušíme:

- hledáme různé alternativy,

- pokoušíme se předvídat výsledky alternativ,

- vytváŕíme si přednostní pořadí alternativ,

- odhadujeme pravděpodobnost, s jakou zvolená alternativa povede $\mathrm{k}$ úspěchu,

- přistoupíme k záměru.

Rozhodování neprobíhá lineárně, jak je uvedeno, rozhodnutí navazuje na již dosažené výsledky, využívána je zpětná vazba.

Úkolem školy je tedy podporovat kariérové rozhodování, v něm hraje významnou roli sebeprezentace žáka. Zastáváme názor, že adekvátní a věrohodná prezentace žáka je podmíněna adekvátním sebepoznáním a na jeho základě vytvořeným sebehodnocením. Ty jsou vztaženy k poznání ,profesní problematiky“, kde technické předměty a výuka o světě práce hrají významnou roli, stejně jako při vytvářené schopnosti rozhodovat se a při vytváření schopnosti sebeprezentace.

\section{Pomoc stř̌ední školy při př́ípravě na kariérové rozhodování žáka (dotazník)}

Cílem dotazníku bylo porovnat, kolik žáci podle jejich názoru dostávají na středních školách informací o možnostech vstupu do profesí, o profesích, o možnostech pomoci při rozhodování atp., tedy informací o širší realitě, nazvěme tuto skupinu položek dotazníku „širší informace“, a kolik dostávají informací o sobě, je-li vytvářeno jejich sebepojetí a sebehodnocení pro kariérové rozhodování, tím také schopnosti sebeprezentace; tuto skupinu položek nazvěme ,informace o žákovi“. Rozdělení položek dotazníku do těchto skupin je dále uvedeno.

Názory žáků jsme zjišt'ovali dotazníkem, jehož respondenty byli studenti 1 . a 2. ročníku na PdF UP, oboru základy technických věd a informačních technologií, a to v průběhu dvou let po sobě. Provedené zjišt'ování nebylo tedy realizováno $\mathrm{s}$ náhodně vybranými respondenty, což ale „vypovídající hodnotu“ podstatněji nesnížilo, viz dále. Celkem tedy bylo rozdáno 116 dotazníků, z nich bylo 6 špatně vyplněno a tudíž vyřazeno z dalšího zpracování. Správně Tab. 1 Přehled hodnocení uvedených výroků dotazníky vyplnilo 33 absolventů gymnázia a zbývajících 77 absolventů odborných škol.

Zmíněný dotazník obsahoval osm položek. Tyto položky obsahovaly výroky uvedené $\mathrm{v}$ tab. 1. Využita byla Likertova škála (od 1 do 5 včetně N). Položka 1 vyjadřuje plný souhlas s výrokem, 5 vyjadřuje plný nesouhlas. Položka $\mathrm{N}$ znamená nevím; byla využita v: otázka číslo 1 (1 absolvent odborné školy), č. 2 (1 absolvent gymnázia, 3 absolventi odborné školy), č. 4 (1 absolvent odborné školy), č. 5 (1 absolvent gymnázia), č. 7 (1 absolvent odborné školy).

Formulovány byly tyto hypotézy:

Hypotéza $\mathrm{H}_{1}$ : Hodnocení jednotlivých osmi položek na středních odborných školách a gymnáziích v roce 2009 bylo stejné jako hodnocení těchto položek na středních odborných školách a gymnáziích v roce 2010.

Hypotéza $\mathrm{H}_{2}$ : Hodnocení jednotlivých osmi položek v roce 2009 bylo na středních odborných školách stejné jako hodnocení těchto položek na gymnáziích.

Hypotéza $\mathrm{H}_{3}$ : Hodnocení jednotlivých osmi položek v roce 2010 bylo na středních odborných školách stejné jako hodnocení těchto položek na gymnáziích.

Hypotéza $\mathrm{H}_{4}$ : Průměrné hodnocení položek v roce 2009 je ve skupině „širší informace“ stejné jako hodnocení položek ve skupině ,informace o žákovi“.

Hypotéza $\mathrm{H}_{5}$ : Průměrné hodnocení položek v roce 2010 je ve skupině „širší informace“" stejné jako hodnocení položek ve skupině ,informace o žákovi“".

Hypotézy $\mathrm{H}_{1}$ až $\mathrm{H}_{3}$ se vztahují především $\mathrm{k}$ homogenitě vzorku podle oborů a $\mathrm{v}$ čase a souvisejí spíš se spolehlivostí závěrů. S podstatou stati souvisejí především hypotézy $\mathrm{H}_{4} \mathrm{a} \mathrm{H}_{5}$, které jsou zacíleny na to, jak vydatně škola poskytuje „Širší informace“ a jak ,informace o žákovi““.

Tab. 1 zachycuje aritmetické průměry hodnocení daného výroku získaného $\mathrm{v}$ obou dotazníkových šetřeních, konaných v letech 2009 a 2010 . 


\begin{tabular}{|c|c|c|c|c|c|c|}
\hline \multirow{2}{*}{ Výrok } & \multicolumn{3}{|c|}{ Dotazníkové šetření z roku 2009} & \multicolumn{3}{|c|}{$\begin{array}{l}\text { Dotazníkové šetření z roku } \\
2010\end{array}$} \\
\hline & Gymnázia & SOŠ & $\begin{array}{c}\text { obě } \\
\text { skupiny }\end{array}$ & gymnázia & SOŠ & $\begin{array}{c}\text { obě } \\
\text { skupiny }\end{array}$ \\
\hline $\begin{array}{l}\text { - Kromě vlastního obsahu výuky mi škola } \\
\text { předala důležité poznatky a dovednosti } \\
\text { související s mým rozhodováním o studiu, } \\
\text { popř́. s uplatněním v profesi. }\end{array}$ & 2,937 & 3,085 & 3,039 & 2,941 & 2,610 & 2,707 \\
\hline $\begin{array}{l}2 \text { - Při identifikaci a formulování mých priorit } \\
\text { (popř. priorit spolužáků) v budoucím studiu a } \\
\text { profesním uplatnění hrála škola významnou } \\
\text { roli. }\end{array}$ & 2,750 & 3,400 & 3,196 & 2,750 & 2,769 & 2,763 \\
\hline $\begin{array}{l}3 \text { - Na škole jsem získal informace o } \\
\text { možnostech budoucího studia nebo také } \mathrm{o} \\
\text { možném budoucím uplatnění. }\end{array}$ & 2,187 & 2,800 & 2,607 & 2,294 & 2,476 & 2,424 \\
\hline $\begin{array}{l}4 \text { - Na škole bylo možno se dozvědět, kde je } \\
\text { možno získat informace o budoucím studiu. }\end{array}$ & 2,000 & 2,485 & 2,333 & 2,118 & 2,122 & 2,120 \\
\hline $\begin{array}{l}5 \text { - Na škole bylo možno se dozvědět, kde lze } \\
\text { získat informace o př́padném nástupu do } \\
\text { profese. }\end{array}$ & 3,187 & 2,382 & 2,640 & 3,470 & 2,810 & 3,000 \\
\hline $\begin{array}{l}6 \text { - Škola mě připravovala na slovní } \\
\text { komunikaci - sebeprezentaci při jednáních o } \\
\text { vstupu do profese nebo studia (výběrová řízení, } \\
\text { konkurzy atp.). }\end{array}$ & 2,687 & 3,650 & 3,352 & 3,294 & 2,881 & 3,000 \\
\hline $\begin{array}{l}7 \text { - Škola mě připravovala na písemnou } \\
\text { komunikaci spojenou se vstupem do profese } \\
\text { nebo studia (strukturovaný životopis atp.). }\end{array}$ & 2,125 & 2,400 & 2,313 & 2,588 & 2,317 & 2,397 \\
\hline $\begin{array}{l}8 \text { - Škola vysvětlila základní aspekty } \\
\text { pracovního poměru, práv a povinností } \\
\text { zaměstnavatelů a zaměstnanců. }\end{array}$ & 2,875 & 2,485 & 2,607 & 3,118 & 2,667 & 2,796 \\
\hline
\end{tabular}

Graf 1 Průměrné hodnocení výzkumných otázek

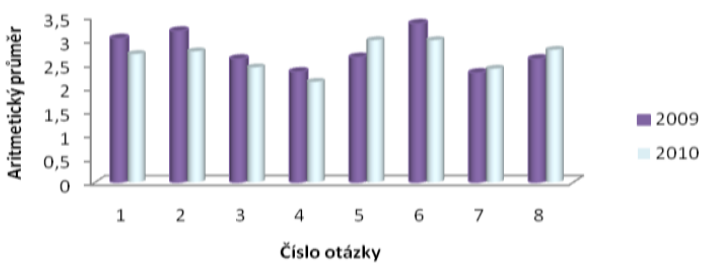

Z tab. 1 jsme pro přehlednost sestavili graf 1 , který obsahuje průměrné hodnocení položek (č. 1-8) v letech 2009, 2010, a to ze sloupce „obě skupiny“ " v tab. 1 (jde o průměr stanovený $\mathrm{z}$ hodnocení gymnázií i středních odborných škol dohromady). Z grafu je zřejmé, že mezi lety 2009 a 2010 nejsou markantní rozdíly $\mathrm{v}$ hodnocení položek. Tento názor jsme ověřili pomocí Studentova t-testu, kdy jsme navzájem porovnávali odpovědi na všech osm uvedených položek, viz výše hypotéza $\mathrm{H}_{1}$.

Při statistickém dokazování hypotézy $\mathrm{H}_{1}$ jsme formulovali nulovou a alternativní hypotézu.

$\mathrm{H}_{01}$ : Mezi hodnocením jednotlivých položek v roce 2009 a 2010 není rozdíl.
$\mathrm{H}_{\mathrm{A} 1}$ : Mezi hodnocením jednotlivých položek $\mathrm{v}$ roce 2009 a 2010 je rozdíl.

Výsledek porovnávání pomocí Studentova ttestu byl následující: u položek č. 3 až 8 nebylo možno odmítnout $\mathrm{H}_{01}(\mathrm{p}>0,05)$, ale u položek č. 1 a 2 byla odmítnuta nulová hypotéza a príijata $\mathrm{H}_{\mathrm{A} 1}(\mathrm{p}<0,05)$. Je tedy zřejmé, že hodnocení jednotlivých položek se většinou neodlišovalo. Odlišnost položek č. 1 a 2 může být způsobena více vlivy, jak celospolečenskými souvislostmi, tak větši pozorností zadavatele dotazníku.

Podobným způsobem jsme prověřovali získaná hodnocení jednotlivých položek absolventy gymnázií a středních odborných škol zvlášt' u každé položky i roku, viz hypotéza $\mathrm{H}_{2}$ a $\mathrm{H}_{3}$. Nejprve jsme se zaměřili na rok 2009. Využili jsme Studentův t-test, kdy jsme porovnávali odpovědi jednotlivě na všech osm uvedených tvrzení u žáků gymnázia a střední odborné školy.

Při statistickém dokazování hypotézy $\mathrm{H}_{2}$ jsme formulovali nulovou a alternativní hypotézu.

$\mathrm{H}_{02}$ : Mezi jednotlivým hodnocením položek na obou typech škol v roce 2009 není rozdíl.

$\mathrm{H}_{\mathrm{A} 2}$ : Mezi jednotlivým hodnocením položek na obou typech škol v roce 2009 je rozdíl. 
Výsledek porovnání pomocí Studentova ttestu byl následující: $\mathrm{H}_{02}$ nebylo možno odmítnout u položek č. $1,3,4,5,7,8$, naopak nulová hypotéza byla odmítnuta a byla přijata $\mathrm{H}_{\mathrm{A} 2}$ u položek č. 2 a 6 . Rozdíly u položek č. 2 a 6 lze vysvětlit odlišným působením obou typů škol v kariérovém rozhodování, viz výše.

Pro rok 2010 byl stanoven stejný postup a obdobná hypotéza $\mathrm{H}_{3}$, obdobně k roku 2009 byly formulovány nulová a alternativní hypotézy $\mathrm{H}_{03}$ a $\mathrm{H}_{\mathrm{A} 3}$. Výsledek porovnání pomocí Studentova ttestu byl následující: $\mathrm{H}_{03}$ nebylo možné odmítnout u všech položek uvedených $\mathrm{v}$ tab. 1 .

Jak již bylo výše naznačeno, pokud se podíváme na tvrzení tvořící položky tab. 1 , zjistíme, že je můžeme rozdělit na tři základní skupiny: ověřující vztah k problematice (pol. č. 1; $\mathrm{s}$ položkou dále nepracujeme), směřující $\mathrm{k}$ „širším informacím“ pro kariérové rozhodování žáka (pol. č. $3-5$, č. 8), směřující k poskytování informací žákovi o něm samém, tedy ,informace o žákovi“ (pol. č. 2, 6, 7). Př́ statistickém dokazování hypotézy $\mathrm{H}_{4}$ zacílené na informování žáků v těchto oblastech a rok 2009, jsme formulovali nulovou a alternativní hypotézu.

$\mathrm{H}_{04}$ : Mezi průměrným hodnocením skupin položek v roce 2009 není rozdíl.

$\mathrm{H}_{\mathrm{A} 4}$ : Mezi průměrným hodnocením skupin položek v roce 2009 je rozdíl.

Při statistickém dokazování obdobné hypotézy $\mathrm{H}_{5}$ jsme „pro rok 2010“ formulovali obdobnou nulovou $\mathrm{H}_{05}$ a alternativní hypotézu $\mathrm{H}_{\mathrm{A} 5}$. Výsledek porovnávání pomocí Studentova t-testu byl následující: $\mathrm{v}$ obou letech jsme museli odmítnout $\mathrm{H}_{04,5}(\mathrm{p}>0,05)$ a přijmout $\mathrm{H}_{\mathrm{A} 4,5}$ $(p<0,05)$. Je tedy zřejmé, že je rozdíl v hodnocení položek ve skupině „ک̌irší informace“ a položek skupiny ,informace o žákovi“ jsou odlišné.

Pozn.: Veškeré výše uvedené výsledky Studentova t-testu se realizovaly v Microsoft Office Excel přes vztah: ttest $\left(\mathrm{A}_{1}: \mathrm{A}_{\mathrm{x}} ; \mathrm{B}_{1}: \mathrm{B}_{\mathrm{x}} ; 1 ; 3\right)$.

Na základě uvedeného můžeme konstatovat, že školám se daří žáky dobře informovat o možnostech kariérové volby $\mathrm{v}$ daných společenských podmínkách, rozhodně je tato činnost školami prováděna lépe než vytváření žákova sebepoznání, sebehodnocení a přiměřené sebeprezentace (zejména „slovní“). To se potvrdilo v roce 2009 i 2010, viz též stati autorů $\mathrm{v}$ časopise Media4U.

\section{Závěr}

Výchova směřující $\mathrm{k}$ dobré profesní orientaci a také ke kariérovému rozhodování žáků souvisí s pěstováním dovedností potřebných pro adekvátní rozhodování o důležitých krocích a pro plánování své vzdělávací a profesní dráhy (i s postupnými cíli pro její realizaci), částečně i pro prvotní kroky realizace přijatých rozhodnutí. Rozhodování se musí opírat o sebepoznání a to ve vztahu $\mathrm{k}$ vnějším možnostem či podmínkám. Jde tedy o to sladit možnosti žáka $s$ potřebami pracovního trhu - technické souvislosti se vyskytují na obou stranách tohoto úkolu. Prožitek rozhodování $\mathrm{v}$ technických předmětech vede také ke zkvalitnění kariérového rozhodování žáka. Žáky, jejich rodinami ani školami není kariérové rozhodování podceňováno.

$Z$ výše uvedeného můžeme usuzovat, že rezervy ve vytváření sebepoznání a sebeprezentace žáků v „,profesních souvislostech“ existují (žáci se dobře neprezentují, protože se neznají). Řešením je zde samostatnost a aktivita, úsilí o plnění cílů vyšší taxace, a konečně tomu odpovídající metody; projektová metoda umožňuje kooperaci, související sebepoznávání a př́mo je vyžadována prezentace toho, co žák vytvořil. Zde je pravděpodobný směr řešení problému, na nějž jsme upozornili.

Je důležité, aby budoucí učitelé technické a informační výchovy byli připravování na řízení samostatných a tvořivých aktivit, kde sebepoznání i sebeprezentace mají své významné místo.

\section{Literatura}

[1] HLAĎO, P. Volba dalši vzdělávací dráhy žákù základnich škol $v$ kontextu rodiny: disertační práce. Brno: Masarykova univerzita, Pedagogická fakulta, Katedra pedagogiky, 2009. 230 s. Školitel doc. PhDr. Zdeněk Friedmann, CSc.

[2] KIROVOVÁ, I. Absolventi, požadavky organizací a systém vzdělávání. In Svět práce a kvalita života v globalizované ekonomice. Díl II. Praha: Výzkumný ústav bezpečnosti práce, 2007. ISBN 978-80-86973-45-6.

[3] KRNINSKÁ, R. Celoživotní učení vedoucí k sladění pracovního a osobního života a vliv kulturních př́stupů. In Svět práce a kvalita života v globalizované ekonomice. Díl II. Praha: Výzkumný ústav bezpečnosti práce, 2007. ISBN 978-80-86973-45-6. 
[4]Projekt „,Kompetence pro trh práce“ [online] Praha, [cit. 2011-04-21]. Dostupné z WWW: <http://www.mamenato.cz/www/index.php> [5]Rámcový vzdélávací program pro základní vzdélávání [online] Praha: Výzkumný ústav pedagogický, 2007. [cit. 2011-04-21]. Dostupné z WWW: $<$ http://www.vuppraha.cz/wpcontent/uploads/2009/12/RVPZV_2007-07.pdf>. [6] STRÁDAL, J. Praktické činnosti pro 6.-9. ročník základních škol: Člověk a svět práce: Príprava na volbu povolání. Praha: Fortuna, 2001. ISBN 80-7168-778-2.

[7] Rámcový vzdělávací program pro gymnázia. [online] Praha: Výzkumný ústav pedagogický, 2007. [cit. 2011-04-21]. Dostupné z WWW: $<$ http://www.vuppraha.cz/wpcontent/uploads/2009/12/RVPG-2007-

07_final.pdf >. ISBN 978-80-87000-11-3.

[8] Rámcový vzdélávací program pro obor vzdělání 23-41-M/01 Strojírenství [online] Praha: Národní ústav odborného vzdělávání, 2007. [cit. 2011-04-21]. Dostupné z WWW: <http://zpd.nuov.cz/RVP/ML/RVP\%202341M01 $\%$ 20Strojirenstvi.pdf>

[9] ČÁP, J. a MAREŠ, J. Psychologie pro učitele. Praha: Portál, 2001. ISBN 80-7178-463-X.

[10] KOSMÁKOVÁ, K. Rozvoj sebepoznáni žáků v rámci tematického okruhu Svět práce na základni škole. Diplomová práce (Vedoucí práce: Mgr. Lenka Hloušková, Ph.D.). [online] Brno: Filozofická fakulta MU, 2009. [cit. 2011-04-21]. Dostupné $\quad \mathrm{z}$ WWW: <http://is.muni.cz/th/259972/ff_m/>

[11] GABRIELOVÁ, J. a GAMBA, R. Poradenská komunikace. Interní materiál zpracovaný pro řešení projektu OPVK „KARIPO“.

[12] FONTANA, D. Psychologie ve školni praxi. Praha: Portál, 2003. ISBN 80-7178-626-8.

[13] HARTL, P. a HARTLOVÁ, H. Psychologický slovník. Praha: Portál, 2000. ISBN 80-7178-303-X.

[14] STERNBERG, R. J. Kognitivní psychologie. Praha: Portál, 2002. ISBN 80-7178-376-5.

doc. PaedDr. Jiří Kropáč, CSc.

Mgr. Anna Zubatá

PhDr. Jitka Plischke, Ph.D.

Katedra technické a informační výchovy

Ústav pedagogiky a sociálních studií

Pedagogická fakulta UP

Žižkovo nám. č. 5

771 40, Olomouc, ČR

Tel: +420 585635805

E-mail: jiri.kropac@upol.cz

Www pracoviště: www.kteiv.upol.cz 